\title{
A PHONETIC CONTRASTIVE ANALYSIS OF ENGLISH WORDS IN THREE JAPANESE SONGS BY AKB48
}

\author{
Harwintha Y. Anjarningsih* \\ Anisa Saraayu ${ }^{* *}$
}

\begin{abstract}
ABSTRAK
Telah banyak penelitian yang mengungkapkan bagaimana penutur bahasa Jepang memiliki perbedaan dalam mengucapkan kata-kata berbahasa Inggris. Namun, tidak banyak penelitian yang menjelaskan penyebab perbedaan tersebut, terlebih lagi mengaitkan perbedaan tersebut dengan pengaruh bahasa ibu. Dengan melakukan perbandingan antara dua struktur bunyi bahasa menggunakan Contrastive Analysis Hypothesis (CAH) dapat dilihat bagaimana bahasa ibu mempengaruhi bahasa asing dan menyebabkan perbedaan pengujaran pada lagulagu populer. Hasil transkripsi dari 3 lagu milik AKB48, Heavy Rotation, Sugar Rush, dan Namida Surpise, dijadikan sumber data untuk melihat pengaruh bahasa ibu. Hasil penelitian menunjukkan penambahan bunyi vokal, perubahan jumlah suku kata, serta perubahan letak artikulasi vokal, penggantian bunyi konsonan dengan konsonan lain, dan penghilangan konsonan terjadi di ketiga lagu. Perubahan perubahan fonetik ini dapat berkontribusi kepada diskusi mengenai hubungan lirik dan melodi pada lagu-lagu yang menggunakan dua atau lebih bahasa (bilingual).
\end{abstract}

Kata Kunci: Bahasa Jepang, Bahasa Inggris, Contrastive Analysis Hypothesis (CAH), Fonetik; Native Language Interference

\begin{abstract}
Many studies have revealed how Japanese speakers pronounce English words differently. However, not much research has explained the causes of the difference, let alone relating such difference with native language interference. By drawing a comparison between the sound structures of the English and Japanese languages using Contrastive Analysis Hypothesis (CAH), we will see how native language may influence foreign language usage and cause pronunciation differences in popular songs. Transcriptions of three AKB48's songs - Heavy Rotation, Sugar Rush, and Namida Surprise - will be used as the data sources to determine native language interference. Our findings show that additions of vowel sounds, changes of syllable, changes of height and place of vowel articulation, replacements of a consonant with another consonant, and elisions of consonants happened to the English words across the three songs. These phonetic changes should inform discussions about the relationship between lyrics and melody in songs that incorporate two or more languages (i.e., bilingual).
\end{abstract}

Keywords: Contrastive Analysis Hypothesis (CAH), English, Japanese, Native Language Interference, Phonetics

* English Study Program, Faculty of Humanities, University of Indonesia.

** English Study Program, Faculty of Humanities, University of Indonesia. 


\section{INTRODUCTION}

With the popularity of Japanese popular music in Indonesia, it is evident to Indonesian listeners that the Japanese songs also incorporate English words in their lyrics. For example, AKB48, a Japanese idol group, has produced approximately 22 songs with English titles. AKB48 began to gain popularity in other, far away countries, such as Indonesia, in 2010. One of their songs, Heavy Rotation, became well-known in Indonesia since its first TV broadcast through an isotonic drink commercial. In Heavy Rotation song alone, there are 19 English words. Some of those words are partially embedded in Japanese sentences, while some others are assembled into English sentences.

What is intriguing is that the English words in the Japanese songs are pronounced in a nativized way which may confuse Indonesian listeners who are more used to listening to Standard American or British English. Indeed, a number of previous studies have found that Japanese face difficulties in speaking English. One of such studies was conducted by Taniguchi and Shibata (2007) from Kochi University, Japan. They asked 35 Japanese university students to speak in English. The results showed that what the students said were often intelligible to native English speakers. For example, when the students said the word 'dog', native speakers interpreted it as 'tock', 'dock', and 'duck'. Gillian Kay (1995) in his study described the changes which occur in the process of borrowing the English language into the Japanese language, ranging from orthographic changes to phonetic changes. However, most of the research is controlled experiments in which the testing devices are prepared in advance. No studies have examined the changes or variations of English pronunciation in Japanese art work such as songs. Some studies even merely provide brief information about the types of changes without any further explanations about native language interference in those changes.

A number of AKB48's songs contain numerous English words. Some of those songs, such as Heavy Rotation, became famous in the international market; some, such as Namida Surprise, also reached the international market but was less successful; and some others, such as Sugar Rush, were made specifically for the international market. Obviously those three songs were produced with different objectives, but this study will focus on how the English language is pronounced in the songs.

In borrowing foreign words - in this case English words - the borrower will not necessarily maintain the conventional pronunciation. Similarly, there are possibilities of pronunciation variations or changes for English loanwords in AKB48 songs. These variations may occur due to a number of aspects, but this study will specifically observe:

1. what kinds of phonetic changes occur in the English loanwords in the three songs;

2. how those changes may be classified; and

3. what causes the differences when seen from a comparison between the English phonetic rules and those of the Japanese language.

The findings from the current study will form an input for musical studies on the relationship between lyrics and melody, such as that "songwriters tend to align salient notes with salient lyrics" (Nichols, Morris, Basu, \& Raphael, 2009: p. 5). It remains to be investigated by (ethno-) musicologists and linguists what functions the changes in phonetics of the words serve, because in the context of the three songs investigated, there seems to be differences in the target market and goal of the song's composition. Another field that may make use of the findings of the present article is sociolinguistics which has long investigated codeswitching and code-mixing phenomena happening between two or more languages (e.g., Stanlaw (2004) for a discussion on Japanese-English codemixing and code-switching). Now, we turn to Contrastive Analysis Hypothesis (CAH) which is used to analyse and compare the English words and their Japanese rendering.

\section{CONTRASTIVE ANALYSIS HYPOTHESIS (CAH)}

Contrastive Analysis method compares the structure of two languages - a native language and a foreign language - in order to see the similarities and the differences between them (Khansir, 2012). This method seeks to explain that the native 
language may affect the structure of the target language. Contrastive Hypothesis is the term for the applied theory, whereas Contrastive Analysis is the method and implementation. The combinaion of the theory, method, and implementation results in Contrastive Analysis Hypothesis/CAH (Yang, 1992). CAH is a linguistic analysis which was started by Bloomfield (1933) before eventually developed by Fries (1945) and Lado (1957) within the structuralism domain. Within the behaviourist domain, CAH is based on a theory by Skinner (n.d.).

According to Hong Ghee Seah (1981) in an article entitled Contrastive Analysis, Error Analysis and Interlanguage in Relation to Adult Chinese Speakers Learning English as a Second Language, there are two versions of CAH: the strong version and the weak version. The strong version of CAH states that all errors in second language learning can be predicted using the contrastive analysis system. In this version, it is believed that a comparison between the students' native language and target language structures can predict what kind of errors the students will make. On the other hand, the weak version of $\mathrm{CAH}$ aims to explain errors which have already occurred instead of predicting what have not yet occurred. In this version, a comparison between the students' native language and target language structures is drawn to observe the similarities and differences, which will explain the errors occuring in language learning.

In A Review of the Contrastive Analysis Hypothesis, Yang (1992) stated that there are four steps in implementing CAH: (1) determining the native language and foreign language to be analysed, (2) choosing the type of analysis to be performed, whether in phonetics, phonology, syntax, or other types, (3) drawing a comparison based on the chosen analysis type, and finally, (4) making a prediction of possible errors. Viewed from the end of the process, it can be deduced that Yang's theory is the strong version of CAH. As for the weak version of $\mathrm{CAH}$, the process stops at step three.

$\mathrm{CAH}$ is sufficient to explain why there are phonetic changes in the pronunciation of English words by Japanese speakers, in this case AKB48. It is adequate to provide an explanation about changes and errors which occur in the use of foreign languages.

Below are the steps done in this research:

(1) Determining the native language and the foreign language to be analysed. This step was taken when selecting the corpus, which are English words in Japanese songs.

(2) Choosing the type of analysis to be performed

(3) Phonetic analysis will be performed. This process involves the transcription process of audio data into written phonetic transcription.

(4) Drawing a comparison based on the selected analysis type

(5) In this study, there will be two comparisons. The first one is a phoneme comparison between English words of Oxford pronunciation and AKB48 pronunciation. The second comparison will be performed at step five.

(6) Classifying the changes which appear

(7) This step does not occur in Yang's (1992) explanation, but it is necessary in order to answer the study questions.

(8) Comparing the sound systems of the English and Japanese languages to explain the errors or changes which are detected during the classification step.

\section{DATA SOURCES}

The primary data of this study are the album version of Heavy Rotation, Namida Surprise, and Sugar Rush audios obtained from various sources on the internet. The data selection was based on several reasons. Heavy Rotation is chosen because the song enjoyed quite a huge popularity that it was adapted into Indonesian and Chinese versions. Namida Surprise is included because it has the biggest number of English words compared to any other AKB48's songs. Finally, Sugar Rush is selected as it was specifically produced for the soundtrack of a Hollywood movie. In other words, this song targets an international audience. The lyrics of the three songs, collected from AKB48's official website (http://stage48.net), are also used as supporting data for this study.

The secondary data are acquired from the 
phonetic transcriptions of the songs by three native Japanese speakers. Two of them are students of Bahasa Indonesia for Non-Native Speakers (BIPA) Programme of Universitas Indonesia. They are assisted by an Indonesian student of Japanese Study Programme of Universitas Indonesia during the transcription process. In the process, the BIPA students are asked to listen to the three selected songs and tell what they hear to the Indonesian student, who then will write down the phonetic transcription. The other native speaker is a Japanese university graduate who majored in Indonesian Literature. Due to distance, his transcription data are sent through emails. The data are after that rechecked by one of the Japanese BIPA students to see whether the transcriptions match the audio data.

\section{METHODS}

Research methodology is a way of conduct to obtain research results. This study uses quantitative method, contrastive analysis, descriptive analysis, and literature research.

In the quantitative method, three Japanese native speakers are asked to listen to the selected songs. Next, they write the English loanwords that they hear in the songs in phonetic symbols. They receive assistance from a Japanese Literature student of Universitas Indonesia during the writing process. To validate the data, short interviews are conducted with other Japanese native speakers who are not involved in the phonetic transcription process to ensure the consistency of the transcription. The data are then compiled and compared with English phonetic symbols. For standard English words, this study refers to English words and phonetic transcriptions in the 8th edition of Oxford Dictionary published in 2010.

In the contrastive analysis method, each word is broken down into phonemes. These phonemes are then compared to the Oxford's version of English phonemes and analysed to observe and find what phonetic changes occurred. This method is also used to draw a comparison between the sound systems of the English and Japanese languages to explain the causes of the changes.

Next, in the descriptive analysis method, the changes identified in the previous comparison are classified into groups. The grouping will be followed by a brief analysis.

Finally, the literature research is used to confirm the hypotheses which emerged during the data management, to explain the methods used for research process and data management, to support the results of performed analyses, and to compare their results.

\section{ANALYSIS}

After collecting the data, 59 English words are found in Namida Surprise, Heavy Rotation, and Sugar Rush songs from AKB48. In the lyrics released on the official website of this idol group, 34 of the English words are written using Latin alphabets, while the remaining 25 are written using katakana characters. Possibly, these 25 are words which are already absorbed. This study will examine all English words, whether absorbed or not, in the three songs.

As basic research materials, the authors ask three Japanese native speakers to listen to the three songs and then write down what they hear in phonetic symbols. Table 2 shows words written using katakana characters, while Table 3 features words written in English. 
Tabel 1.

English loanwords written using katakana characters

\begin{tabular}{|c|c|c|c|c|c|}
\hline No. & Katakana & $\begin{array}{l}\text { Romaji (the words written in } \\
\text { roman letters by Japanese) }\end{array}$ & English words & English IPA symbols & $\begin{array}{l}\text { Japanese } \\
\text { pronunciation }\end{array}$ \\
\hline 1 & ベル & Beru & Bell & [bel] & beru \\
\hline 2 & バスケットボール & Basukettobooru & Basketball & [‘ba:skItbכ:1] & basurketobooru \\
\hline 3 & ゴール & Gooru & Goal & [gəol] & gooru \\
\hline 4 & クラスメイト & Kurasumeito & Classmate & [kla:smeIt] & kurasumeIto \\
\hline 5 & アイマスク & Aimasuku & Eye-mask & [aIma:sk / mæsk] & aimasuku \\
\hline 6 & クラッカー & Kurakkaa & Cracker & {$[\operatorname{krækə}(\mathrm{r})]$} & kuraka \\
\hline 7 & ケーキ & Keeki & Cake & [keIk] & keeki \\
\hline 8 & キャンドル & Kyandoru & Candle & [kændl] & kjandoru \\
\hline 9 & パーティー & Paatii & party & [pa:rtI / pa:tI] & paatii \\
\hline 10 & サプライズ & Sapuraizu & Surprise & [sə’praIz] & sapuraiczu \\
\hline 11 & コップ & Koppu & Cup & {$[\mathrm{k} \Lambda \mathrm{p}]$} & koopu \\
\hline 12 & プレゼント & Purezento & Present & [preznt] & pureckeento \\
\hline 13 & セブンティーン & Sebuntiin & Seventeen & [sevn'tI:n] & sebuntin \\
\hline 14 & ピースし & Piisu & Peace & [pI:s] & pi:su \\
\hline 15 & タイム & Taimu & Time & {$[\mathrm{taIm}]$} & taim \\
\hline 16 & カプセル & Kapuseru & Capsule & [kæpsju:1] & kapuseru \\
\hline 17 & ポップコーン & Poppukoon & Popcorn & [popkว:n] & po:pukoon \\
\hline 18 & ハイ & Hai & High & [haI] & haI \\
\hline 19 & テンション & Teshin & Tension & {$\left[\operatorname{ten} \int \mathrm{n}\right]$} & te:fon \\
\hline 20 & イマジネーション & Imajineeshon & Imagination & [Imæd3IneIJn] & imackinee on \\
\hline 21 & ハイウェイ & Haiuei & Highway & [haIweI] & haweI \\
\hline 22 & ガソリン & Gasorin & Gasoline & [gæsəli:n] & gasorinu \\
\hline 23 & ハート & Haato & Heart & [ha:rt] & ha:to \\
\hline 24 & グッド & Guddo & Good & [god] & guudo \\
\hline 25 & ラック & Rakku & Luck & {$[1 \Lambda \mathrm{k}]$} & raaku \\
\hline
\end{tabular}

Tabel 2.

English loanwords written using Latin alphabets

\begin{tabular}{|c|c|c|c|c|c|c|c|}
\hline No & Word & $\begin{array}{l}\text { IPA of the words' } \\
\text { English pronunciation }\end{array}$ & $\begin{array}{c}\text { IPA of the words' } \\
\text { pronunciation by } \\
\text { AKB48 }\end{array}$ & No & Word & $\begin{array}{l}\text { IPA of the words' } \\
\text { English pronunciation }\end{array}$ & $\begin{array}{c}\text { IPA of the words' } \\
\text { pronunciation by } \\
\text { AKB48 }\end{array}$ \\
\hline 1 & Happy & hæpi & hap'i & 18 & Max & mæks & maakusu \\
\hline 2 & Birthday & b3:өdeI & basurde & 19 & Feel & fi:1 & fiiru \\
\hline 3 & To & tu: & tu & 20 & Touch & $\mathrm{t} \Lambda \mathrm{t} \int$ & ta \\
\hline 4 & You & ju & ju & 21 & Hold & hoold & ho \\
\hline 5 & Dear & $\mathrm{dI}(\mathrm{r})$ & dir & 22 & $\mathrm{~S}$ & es & esur \\
\hline 6 & My & $\mathrm{maI}$ & $\mathrm{ma}$ & 23 & $\mathrm{U}$ & ju: & ju \\
\hline 7 & Friend & frend & fen & 24 & G & dzi: & dzi \\
\hline 8 & Good & god & guudo & 25 & A & eI & $\mathrm{e}$ \\
\hline 9 & Luck & $1 \Lambda \mathrm{k}$ & raaku & 26 & $\mathrm{R}$ & $\mathrm{a}:(\mathrm{r})$ & aru \\
\hline 10 & I & aI & ai & 27 & Jump & $\mathrm{d} 3 \Lambda \mathrm{mp}$ & dzamp \\
\hline 11 & Want & wont / wa:nt / wכ:nt & won & 28 & Into & Intə & intur \\
\hline 12 & You & ju: & $\mathrm{t} \int \mathrm{u}:$ / ḑu / bju: & 29 & Your & jə:(r ) / jə ( r ) & jua \\
\hline 13 & Need & nI:d & ni: & 30 & Racing & reIsIn & reifin \\
\hline 14 & Love & $1 \Lambda \mathrm{v}$ & ra & 31 & Car & ka: (r) & ka \\
\hline 15 & Music & mju:zIk & mjuudziiku & 32 & Sugar & Jugə (r) & furga \\
\hline 16 & Heavy & hevi & hebbii & 33 & Rush & $\mathrm{r} \Lambda \mathrm{s}$ & $\mathrm{ra}$ \\
\hline 17 & Rotation & rəฮ’teI $\int \mathrm{n}$ & rootee $\int o n$ & & & & \\
\hline
\end{tabular}




\section{Results}

After conducting a phonetic transcription on each English word in the three songs, it is found that there are some differences which arise from the process of absorbing, borrowing, or using English. Those differences are:

a) Additions of vowel sound;

b) Changes of syllable;

c) Changes of height and place of vowel articulation;

d) Replacements of a consonant with another consonant; and

e) Elisions of consonant.

\section{A. Additions of Vowel Sound}

Through word per word analysis on the collected data, the authors find that there are additions of vowel sound in two positions: at the end of words and between consonant clusters.

At the end of several words, there are additions of vowels/a/, /i/, /u/, /e/, and /o/. Below is a table showing vowels added at the end of words as well as word examples. There may be a specific structure to determine which vowel will be added at the end of a word; however, the data show that there is no particular structure. For instance, $/ \mathrm{k} /$ is followed by /u/ in the word 'raku' from 'luck', but it is followed by /a/ in the word 'kuraka' from 'cracker'.

Besides at the end of words, vowel additions also occur between consonant clusters. The data show that only /u/ and /o/ appear between consonant clusters. However, considering that this study uses a limited amount of data, it does not mean that any vowels other than those two cannot appear between consonant clusters.

The majority of vowel additions between consonant clusters occur in Namida Surprise, amounting to 9 out of 25 English words. There is only one vowel addition between consonant clusters in Heavy Rotation, and no such addition in Sugar Rush.

Tabel 3.

Vowel additions found in the data

\begin{tabular}{|c|c|c|c|c|c|}
\hline No. & Vowel & & Previous consonant & Source word & Word in the song \\
\hline 1 & {$[\mathrm{u}]$} & $\begin{array}{l}\text { Rounded closed back } \\
\text { vowel }\end{array}$ & {$[\mathrm{r}]$ short voiced alveolar flap } & Bell & beru \\
\hline 2 & & & & Goal & goru \\
\hline 3 & & & & Feel & firu \\
\hline 4 & & & & Basketball & basuketoboru \\
\hline 5 & & & & Candel & kyandoru \\
\hline 6 & & & & Capsule & kapuseru \\
\hline 7 & & & [c] alveolar dental affricate & Surprise & sapuraizu \\
\hline 8 & & & {$[\mathrm{k}]$ voiceless velar plosive consonant } & Eye-mask & aimasuku \\
\hline 9 & & & & Music & myujiku \\
\hline 10 & & & $\begin{array}{l}\text { [p] voiceless bilabial plosive } \\
\text { consonant }\end{array}$ & Cup & kopu \\
\hline 11 & & & {$[\mathrm{~s}]$ voiced alveolar fricative } & Peace & pisu \\
\hline 12 & & & {$[\mathrm{k}]$ voiceless velar plosive consonant } & Luck & raku \\
\hline 13 & [i] & $\begin{array}{l}\text { Spread closed front } \\
\text { vowel }\end{array}$ & [k] voiceless velar plosive consonant & Cake & keki \\
\hline 14 & & & $\begin{array}{c}{[\mathrm{t}] \text { voiceless alveolar plosive }} \\
\text { consonant }\end{array}$ & Party & pati \\
\hline 15 & [o] & $\begin{array}{l}\text { Rounded mid-closed } \\
\text { back vowel }\end{array}$ & [d] voiced alveolar plosive consonant & good & guudo \\
\hline 16 & & & $\begin{array}{c}{[\mathrm{t}] \text { voiceless alveolar plosive }} \\
\text { consonant }\end{array}$ & Hat & hato \\
\hline 17 & & & & Classmate & Kurasumeito \\
\hline
\end{tabular}




\begin{tabular}{|c|c|c|c|c|c|}
\hline No. & Vowel & & Previous consonant & Source word & Word in the song \\
\hline 18 & & & & Present & purezento \\
\hline 19 & & & & Favorite & febarito \\
\hline 20 & {$[\mathrm{u}]$} & $\begin{array}{l}\text { Unrounded closed } \\
\text { back vowel }\end{array}$ & {$[\mathrm{s}]$ voiceless alveolar fricative } & $\max$ & Makusu \\
\hline 21 & & & & $\mathrm{~s}$ & /esu/ \\
\hline 22 & & & [n] nasal alveolar sonorant consonant & Gasoline & gasorinu \\
\hline 23 & [a] & $\begin{array}{l}\text { Unrounded open front } \\
\text { vowel }\end{array}$ & {$[\mathrm{k}]$ voiceless velar plosive consonant } & Cracker & kuraka \\
\hline 24 & [e] & $\begin{array}{l}\text { Spread close-mid } \\
\text { front vowel }\end{array}$ & [d] voiced alveolar plosive consonan & Birthday & basude \\
\hline
\end{tabular}

\section{B. Changes of Syllables}

Vowel additions at the end of words and between consonant clusters cause syllable changes. In Phonological Differences between Japanese and English: Several Potentially Problematic Areas of Pronunciations for Japanese ESL/EFL Learners, Ohata (2004) explains that "....Japanese words of more than one syllable always follow the
CV-CV-CV syllable sequence". The data in this study show that indeed there aresyllable changesin English words used by AKB48, whether written using katakana characters or Latin alphabets.

This type of change appears in almost all English wordsin the three Japanese songs examined, except in the words 'happy', 'to', 'you', 'need', 'heavy', 'into', and 'I'.

Tabel 4.

Vowel additions between consonant clusters in the data

\begin{tabular}{|c|c|c|c|c|c|c|}
\hline No. & Vowel & & Previous consonant & Following consonant & Source word & Word in the song \\
\hline \multirow[t]{8}{*}{1} & {$[\mathrm{u}]$} & $\begin{array}{l}\text { Back closed } \\
\text { vowel }\end{array}$ & $\begin{array}{l}\text { [s] voiceless alveolar } \\
\text { fricative }\end{array}$ & $\begin{array}{l}{[\mathrm{k}] \text { voiceless velar }} \\
\text { plosive consonant }\end{array}$ & basuketoboru & basketball \\
\hline & & & & & aimasuku & eye-mask \\
\hline & & & $\begin{array}{l}{[\mathrm{k}] \text { voiceless velar }} \\
\text { plosive consonant }\end{array}$ & $\begin{array}{l}{[\mathrm{r}] \text { short voiced }} \\
\text { alveolar flap }\end{array}$ & kurasumeito & classmate \\
\hline & & & & & kuraka & cracker \\
\hline & & & $\begin{array}{l}\text { [s] voiceless alveolar } \\
\text { fricative }\end{array}$ & $\begin{array}{l}{[\mathrm{m}] \text { nasal bilabial }} \\
\text { sonorant consonant }\end{array}$ & Kurasumeito & classmate \\
\hline & & & $\begin{array}{l}\text { [p] voiceless bilabial } \\
\text { plosive consonant }\end{array}$ & $\begin{array}{c}{[\mathrm{r}] \text { short voiced }} \\
\text { alveolar palatalized } \\
\text { flap }\end{array}$ & Purezento & Present \\
\hline & & & $\begin{array}{l}\text { [p] voiceless bilabial } \\
\text { plosive consonant }\end{array}$ & $\begin{array}{l}\text { [s] voiceless alveolar } \\
\text { fricative }\end{array}$ & kapuseru & capsule \\
\hline & & & $\begin{array}{l}\text { [p] voiceless bilabial } \\
\text { plosive consonant }\end{array}$ & $\begin{array}{l}{[\mathrm{k}] \text { voiceless velar }} \\
\text { plosive consonant }\end{array}$ & Popukon & popkorn \\
\hline \multirow[t]{2}{*}{2} & [u] & $\begin{array}{l}\text { Unrounded } \\
\text { back closed } \\
\text { vowel }\end{array}$ & $\begin{array}{l}\text { [p] voiceless bilabial } \\
\text { plosive consonant }\end{array}$ & $\begin{array}{l}\text { [r] short voiced } \\
\text { alveolar flap }\end{array}$ & sapuraizu & surprise \\
\hline & & & $\begin{array}{l}\text { [s] voiceless alveolar } \\
\text { fricative }\end{array}$ & $\begin{array}{l}\text { [d] voiced alveolar } \\
\text { plosive consonant }\end{array}$ & basude & basude \\
\hline \multirow[t]{2}{*}{3} & {$[0]$} & $\begin{array}{l}\text { rounded back } \\
\text { mid-closed } \\
\text { vowel }\end{array}$ & $\begin{array}{l}\text { [t] voiceless alveolar } \\
\text { plosive consonant }\end{array}$ & $\begin{array}{l}{[\mathrm{b}] \text { voiced bilabial }} \\
\text { plosive consonant }\end{array}$ & Basuketoboru & basketball \\
\hline & & & $\begin{array}{l}\text { [d] voiced alveolar } \\
\text { plosive consonan }\end{array}$ & $\begin{array}{l}\text { [r] short voiced } \\
\text { alveolar flap }\end{array}$ & Kyandoru & candle \\
\hline
\end{tabular}


Tabel 5.

Examples of words which undergo syllable changes

\begin{tabular}{|c|c|c|c|c|}
\hline No. & Word & Syllable pattern & AKB48 version & Syllable pattern \\
\hline 1 & Bell & $\mathrm{CVC}$ & Beru & $\mathrm{CVCV}$ \\
\hline 2 & Basketball & CVCCVCCVC & basuketobooru & CVCVCVCVCVVCV \\
\hline 3 & Goal & CVVC & Gooru & CVVCV \\
\hline 4 & Classmate & CCVCCVVC & kurasumeito & CVCVCVCVVCV \\
\hline 5 & Eye-mask & VVCVCC & aimasuku & VVCVCVCV \\
\hline 6 & Cracker & CCVCVC & kuraka & CVCVCV \\
\hline 7 & Cake & CVVC & Keeki & CVVCV \\
\hline 8 & Candle & CVCCC & kjandoru & CCVCCVCV \\
\hline 9 & party & CVCCV & paatii & CVVCVV \\
\hline 10 & Surprise & CVCCVVC & sapuraizu & CVCVCVVCV \\
\hline 11 & Cup & $\mathrm{CVC}$ & koopu & CVVCV \\
\hline 12 & Present & $\mathrm{CCVCCC}$ & purezento & CVCVCVCCV \\
\hline 13 & Seventeen & CVCCCVC & sebuntiin & CVCVCCVVC \\
\hline 14 & Peace & $\mathrm{CVC}$ & piisu & CVVCV \\
\hline 15 & Time & CVVC & taim & CVVC \\
\hline 16 & Capsule & CVCCCVC & kapuseru & CVCVCVCV \\
\hline 17 & Popcorn & CVCCVC & popukon & CVCVCVC \\
\hline 18 & High & CVV & hai & CVV \\
\hline 19 & Tension & CVCCC & teshon & CVCCVC \\
\hline 20 & Imagination & VCVCVCVVCC & imazineshon & VCVCVCVCCVC \\
\hline 21 & Favorite & CVVCVCVC & febarito & CVCVCVCV \\
\hline 22 & Song & $\mathrm{CVC}$ & son & $\mathrm{CVC}$ \\
\hline 23 & Say & $\mathrm{CVV}$ & se & $\mathrm{CV}$ \\
\hline 24 & Highway & CVVCVV & hawei & CVCVV \\
\hline 25 & Gasoline & CVCVCVC & gasorinu & CVCVCVCV \\
\hline
\end{tabular}

\section{Changes of height and place of articulation}

Another type of change which occurs during the process of borrowing or using English words by AKB48 is changes of vowel pronunciation in terms of place and height of articulation. Vowels are classified by their height and place. Vowel height is the distance between articulators. The higher the tongue position is, the higher the vowel sound produced. Vowel place, on the other hand, is the highest part of the tongue, whether it is the front, which is referred to as palatal, or the back, which is referred to as velar (Davenport \& Hannahs, 2005, p. 38-38). The initial hypothesis is that this is an attempt to simplify vocal sounds.

The changes which occur are as follows: a) The vowel /a/ always changes to the low central vowel [a]

e.g.: Car [ka: r] becomes [ka]

The $\mathrm{K}[\mathrm{k}]$ is a voiceless velar plosive consonant.

The long low back vowel A [a:] is replaced by the short low central vowel [a].

b) The vowel /i/ remains a high front vowel, but tends to change to the tense form than the lax form (Miller, 1970) e.g.: Racing [reIsIn] becomes /resin/ [reifin]

The $\mathrm{R}[\mathrm{r}]$ is an alveolar plosive flap consonant.

The $\mathrm{E}[\mathrm{e}]$ is a short mid front vowel.

The lax high front vowel I [I] is replaced 
by the tense high front vowel [i].

The voiceless alveolar fricative $\mathrm{S}[\mathrm{s}]$ is replaced by the voiceless palato-alveolar fricative and rather thin [J].

The lax high front vowel I [I] is replaced by the tense high front vowel I [i].

The sonorant nasal velar $N$ [y] is replaced by the sonorant nasal alveolar [n].

c) The vowel $/ \mathrm{u} /$ always changes to the high back vowels $[u]$ and [u].

e.g.: Good [god] becomes [guudo]

The $\mathrm{G}[\mathrm{g}]$ is a voiceless velar plosive consonant.

The high back vowel $\mathrm{U}[\mathrm{u}]$ replaces [ $\mathrm{\mho}]$, which is also a high back vowel, but shorter and more central. There are two $[u] s$ in these words, each of which is a stand-alone.

The D [d] is a voiced alveolar plosive consonant.

The $\mathrm{O}[\mathrm{o}]$, added at the end of the word, is a mid-back vowel.

\section{Replacements of a Consonant with Another Consonant}

In several words, a consonant is replaced by another when the sound is not available in the mother tongue. This issue will be further elaborated in the next section.

The most often consonant change occurs from the alveolar liquid [1] to the alveolar flap [r]. Below are some examples of words with changed [1] sound.

Bell

Basketball

Goal

Classmate

Feel

Gasoline

The above examples show that an [1] sound in any positions will be replaced by the $[\mathrm{r}]$ sound.

Other consonant changes occur in the ' $z$ ' and 'j' sounds. In English, ' $z$ ' is normally denoted by the phonetic symbol [z], an alveolar fricative. On the other hand, ' $\mathrm{j}$ ' is phonetically denoted by [d]], a voiced palato-alveolar affricate. However, from the data obtained, both $[\mathrm{z}]$ and [d] sounds often become the dental-alveolar affricate [dz]. The examples of such changed words are as follows.

\begin{tabular}{|c|c|c|}
\hline ump & {$[\mathrm{d} s \Lambda \mathrm{mp}]$} & [camp] \\
\hline urprise & [sə'praIz] & puraiczu] \\
\hline & [preznt] & reckeento] \\
\hline agination & [ImædyIneI $\left.\int \mathrm{n}\right]$ & [imadzinee on] \\
\hline
\end{tabular}

However, this does not apply to the word / music/. In Heavy Rotation, [mju: Zik] changes into [mjuudziiku].

Consonant changes also occur in the word 'seventeen', in which the /v/ sound is replaced with the $/ \mathrm{b} /$ sound. [V] is a labio-dental fricative, whereas $[\mathrm{b}]$ is a bilabial plosive.

\section{E. Elisions of Consonants}

Consonant elisions are found in consonant clusters and stand-alone consonants in the three songs. In the English language, the omission of sounds in conversations is known as elision. It usually occurs in conversational context when a consonant meets another consonant. For instance, the word 'them' in a conversation may be pronounced as 'em, in which the sound [ð] is omitted. However, the consonant elisions found in the data of this study are different. First of all, the elisions here occur in word level, not in sentence level. Secondly, they occur during the language borrowing process by non-English speakers.

Below are the examples of words in which consonant elisions occur.

$\begin{array}{lll}\text { Friend } & {[\text { frend }]} & {[\mathrm{fen}]} \\ \text { Love } & {[1 \Lambda \mathrm{v}]} & {[\mathrm{ra}]} \\ \text { Touch } & {[\mathrm{t} \Lambda \mathrm{t}]} & {[\mathrm{ta}]}\end{array}$

Different cases occur in the words 'friend', 'love' and 'touch'. The word 'friend' loses the[r] and [d] sounds. The word 'love' loses the [v] sound, while the word 'touch' loses the [t] sound. The final sound of the three words is elided, except in the word 'friend' in which the $[\mathrm{r}]$ soundis also omitted.

\section{CONTRASTIVE ANALYSIS BETWEEN SOUND STRUCTURE OF ENGLISH AND JAPANESE}

After the difference classifications and explanations in the two previous sections, this 
last section will elaborate the relation between the differences that occur using the native language phonetic system. The influence of native language phonetic rules to the borrowed language, in this case English, will be explained using Contrastive Analysis Hypothesis (Ohata, 2004). This analytical method is often used before to find pronunciation errors in foreign language learning by comparing the phonetic systems of the native and target languages. Although this method is typically used in the teaching field, it is also able to explain how the native language may influence the target language and cause the differences mentioned in the previous sections.

The first is a comparison between the Japanese and English vowels. There are 15 vowels in English, while the Japanese language only has five vowels.

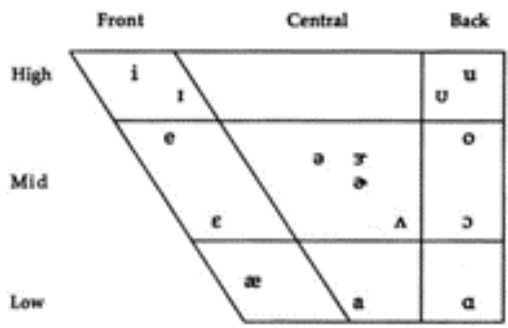

Figure 1. English vowels. Taken from Minnesota State University website (www.mnsu.edu)

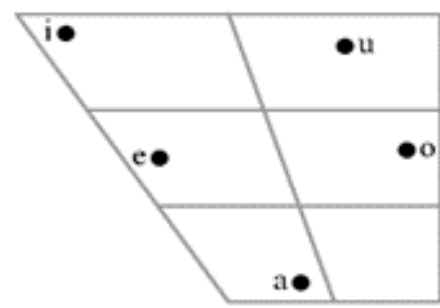

Figure 2. Japanese vowels. Taken from commons. wikimedia.org

The figures above show that the Japanese language has fewer vowels than the English language. This leads to some other differences, including vowel tenseness. According to Figure 2, English has two vowel forms. The vowel /i/, for instance, has the tense form [i] and the lax form [I]. In Japanese, however, that vowel only has the tense form [i]. This explains why there are changes in the /i/ sound of the English words in the three songs examined.

The vowel difference also explains changes in the place and height of vocal articulation such as in the word /car/, where the short low central vowel [a] replaces the long low back vowel [a:]. The absence of [a:] sound in the Japanese phonetic system causes adjustment to the more familiar vocal sound.

The next one is a comparison between the English and Japanese consonants.

Tabel 6.

Japanese consonants (Ohata, 2004)

\begin{tabular}{|l|l|l|l|l|l|l|l|l|}
\hline $\begin{array}{l}\text { Place of Articulation } \\
\text { Manner of Articulation }\end{array}$ & Bilabial & Labiodental & Interdental & Alveolar & Alveopalatal & Velar & Glottal \\
\hline \multirow{2}{*}{ Stops } & Voiceless & $\mathrm{p}$ & & & $\mathrm{t}$ & & $\mathrm{k}$ & \\
\hline & Voiced & $\mathrm{b}$ & & & $\mathrm{d}$ & & $\mathrm{g}$ & \\
\hline \multirow{2}{*}{ Fricatives } & Voiceless & & $\mathrm{f}$ & $\mathrm{f}$ & $\mathrm{s}$ & $\mathrm{l}$ & & $\mathrm{h}$ \\
\hline & Voiced & & $\mathrm{v}$ & $\mathrm{d}$ & $\mathrm{z}$ & $\mathrm{3}$ & & \\
\hline \multirow{2}{*}{ Affricates } & Voiceless & & & & & $\mathrm{t}$ & & \\
\hline & Voiced & & & & & ds & & \\
\hline Nasals & & $\mathrm{m}$ & & & $\mathrm{n}$ & & & \\
\hline Retroflex Liquid & & & & $\mathrm{r}$ & & & \\
\hline Lateral Liquid & & & & 1 & & & \\
\hline
\end{tabular}

Tabel 7.

English consonants (Ohata, 2004)

\begin{tabular}{|c|c|c|c|c|c|c|c|c|}
\hline \multicolumn{2}{|c|}{$\begin{array}{l}\text { Place of Articulation } \\
\text { Manner of Articulation }\end{array}$} & Bilabial & \multirow[t]{2}{*}{ Labiodental | } & Interdental & Alveolar & Alveopalatal & Velar & Glottal \\
\hline \multirow{2}{*}{ Stops } & Voiceless & p & & & $t$ & & $\mathrm{k}$ & \\
\hline & Voiced & $b$ & & & d & & $g$ & \\
\hline \multirow{2}{*}{ Fricatives } & Voiceless & & f & $\theta$ & $\mathrm{s}$ & f & & h \\
\hline & Voiced & & V & $\delta$ & $z$ & 3 & & \\
\hline \multirow{2}{*}{ Affricates } & Voiceless & & & & & $t$ & & \\
\hline & Voiced & & & & & $d s$ & & \\
\hline \multicolumn{2}{|l|}{ Nasals } & $\mathrm{m}$ & & & n & & & \\
\hline \multicolumn{2}{|c|}{ Retroflex Liquid } & & & & r & & & \\
\hline \multicolumn{2}{|c|}{ Lateral Liquid } & & & & , & & & \\
\hline
\end{tabular}

In general, English has more varied consonant sounds. Some sounds do not exist in Japanese, while some others do not exist in English. The tables above show that the Japanese language does not have any labiodental consonant such as [f] and [v]. Furthermore, there is only one liquid consonant, and even that is merely an approximant liquid, not retroflex or lateral. In English, differently, a number of consonants such as [t] and [k] do not exist. It should be noted that two tables of Japanese consonants are presented 
above. The one with more consonants has more likely been adapted. As time goes by, the Japanese language begins to adapt to foreign consonant sounds. As described by Gillian Kay (1995) in his article English Loanwords in Japanese, the Japanese language over time is getting better to produce sounds similar to the original.

This difference explains consonant changes which take place in the three songs. English consonants are transformed into sounds which are more familiar to the Japanese mother tongue. However, from the existing data, it is unclear why certain consonants are selected over the others.

The third and last comparison will be for syllables. English words contain many consonant clusters. In fact, there are some words which only consist of consonants without any vowel at all.

\section{Word \\ Crack \\ Practice

Syllable Structure
CCVC
CCVCCVC

The examples show that English words follow no certain syllable structures. This is very different from the Japanese language, in which, based on the Japanese vocabulary and syllable structure, consonant clusters never occur.

$\begin{array}{lll}\text { Meaning } & \text { Form } & \text { Syllable Structure } \\ \text { Kuro } & \text { black } & \text { CVCV } \\ \text { Sakebi } & \text { cry } & \text { CVCVCV } \\ \text { Watashi } & \text { I } & \text { CVCVCV }\end{array}$

These examples show that Japanese words tend to maintain the CV-CV-CV structure.

Aside from that, all Japanese words always terminate in a vowel. An exception is made for the consonant $/ \mathrm{n} /$, the only stand-alone consonant which can be found at the end of a word, such as in the word 'shomen'. As we can see in the examples above, every other consonant is always paired with a vowel. Hence, the Japanese word formation always follows the CV-CV-CV structure.

\section{CONCLUSION}

In the three songs that have been analysed by Contrastive Analysis Hypothesis (CAH), changes in the pronunciation of the English words were found. The changes include: additions of vowel sounds, changes of syllable, changes of height and place of vowel articulation, replacements of a consonant with another consonant, and elisions of consonants, and are influenced by the consonant and vowel inventory and structures of the Japanese language. However, these changes do not occur in a similar number across the three songs. Changes such as addition of vowel sounds among the consonants in consonant clusters did not happen in Sugar Rush song, but they occurred in 17 out of 25 words in Namida Surprise. Therefore, the present results should be discussed in a cross-discpline article incorporating the disciplines of linguistics and musicology or phonetics and sociolinguistics in order to shed more light on why the changes are like what they are and what functions they may serve in the context of popular music and culture, and relationships between lyrics and melody.

\section{REFERENCES}

Bloomfield, Leonard. (1993). An Introduction to the Study of Language. New York: Holt

Brown, H., D. (2007). Principles of Language Learning and Teaching. London: Pearson Longman

Collin, B., Mees, I.M. (2003). Practical Phonetics and Phonology. London: Routledge.

Davenport, M, \& Hannahs, S.J. (2005). Introducing Phonetics and Phonology. New York: Oxford University Press Inc.

Fries, C. C. (1945). Teaching and Learning English as Second Language. University of Michigan Press

Kay, Gillian. (1995). English loanwords in Japanese. World Englishes, pp. 67-76.

Khansir, A. A. (2012). Error analysis and second language acquisition. Theory and practice in language studies, 1027-1032.

Lado, R. (1957). Linguistic across culture: Applied linguistic for language teachers. University of Michigan Press.

Miller, R. (Ed.). (1970). Bernard Bloch on Japanese. London: Yale University.

Nichols, E., Morris, D., Basu, S., \& Raphael, C. (2009). Proceeding of the 2009 ISMIR (The International Society for Music Information Retrieval) Conference

Ohata, K. (2004). Phonological differences between Japanese and English: Several potentially problematic areas of pronunciation for Japanese 
ESL/EFL learners. Asian ELF Journal.

Pennycook, A. (1994). The Cultural Politics of English as an International Language. Longman Group: Singapore.

Rohde, D. (1996). As English Spreads, Speakers Morph it into World Tongue, Christian Science Monitor.

Seah, Hong Ghee. (1981). Contrastive analysis, error analysis and interlanguage in relation to Chinese speakers learning English as a Second language. (Unpublished doctoral dissertation). Simon Fraser University, Burnaby, Canada. Skinner, B. F. (n.d). Verbal behaviour. Copley Publishing
Group.

Stanlaw, James. (2004). Japanese English: Language and Culture Contact. Hong Kong: Hong Kong University Press.

Sudjianto, D., Dahidi, D.A. (2007). Bunyi bahasa dalam bahasa Jepang. In D. S., \& D. A. Dahidi, Pengantar linguistik Bahasa Jepang (p. 22). Jakarta: Oriental.

Taniguchi, M., \&Shibata, Y. (2007). Japanese learners' English pronunciation: how intelligible is it? Kochi University.

Yang, B.-G. (1992). A review of the contrastive analysis hypothesis. Dongeui Journal 19, 133-149. 